\title{
GAYA BAHASA PERBANDINGAN PADA KUMPULAN PUISI DALAM PEMBELAJARAN SASTRA DI SMA
}

\author{
Sahrul Umami \\ Puji Anto \\ Universitas Indraprasta PGRI \\ TB. Simatupang, JI. Nangka Raya No.58 C, RT.5/RW.5, Tj. Bar., Kec. Jagakarsa, Kota \\ Jakarta Selatan, Daerah Khusus Ibukota Jakarta 12530 \\ umamisahrul@gmail.com
}

Naskah masuk: 12-10-20, direvisi: 21-01-20, diterima: 12-02-20, dipublikasi: 30-04-20

\begin{abstract}
Abstrak: Karya tulis ini mendeskripsikan gaya bahasa perbandingan pada kumpulan puisi Kwatrin Untuk Kekasih karya Waluya Ds dalam pembelajaran sastra di SMA. Penelitian ini bertujuan mengetahui penggunaan gaya bahasa perbandingan pada kumpulan puisi Kwatrin Untuk Kekasih karya Waluya Ds dalam pembelajaran sastra di SMA. Metode yang digunakan dalam penelitian ini adalah metode deskriptif kualitatif dengan teknik analisis isi. Penulis berusaha mendeskripsikan gaya bahasa perbandingan pada kumpulan puisi Kwatrin Untuk Kekasih Karya Waluya Ds dalam pembelajaran sastra di SMA. Hasil penelitian ini terdapat gaya bahasa perbandingan jenis alegori, alusio, hiperbola, metafora, personifikasi, simile, dan sinekdoke (pars pro toto dan totum pro parte). Pembelajaran sastra di SMA bahwa kumpulan puisi tersebut dapat dijadikan media pembelajaran. Simpulan dalam penelitian ini, pengajaran mengenai gaya bahasa dalam kumpulan puisi tersebut dapat mengembangkan kreativitas siswa dalam memilih kata dan merangkai kata-kata sampai menghasilkan karya sastra yang memiliki nilai estetis.
\end{abstract}

Kata kunci: Gaya Bahasa, Perbandingan, Puisi, Pembelajaran Sastra

\begin{abstract}
This paper describes the comparative linguistic style of the collection of poetry Kwatrin Untuk Kekasih by Waluya Ds in the study of literature in high school. This study aims to determine the use of comparative language in the collection of poetry Kwatrin For Lovers by Waluya Ds in high school literary learning. The method used in this study is a qualitative descriptive method with content analysis techniques. The author tries to describe the comparative linguistic style of the collection of poetry Kwatrin For Lover's Work Waluya Ds in studying literature in high school. The results of this study are comparative language styles of allegory, alusio, hyperbole, metaphor, personification, simile, and sinekdoke (pars pro toto and totum pro parte). Literary learning in high school that the collection of poetry can be used as learning media. The conclusion of this research, teaching about language style in a collection of poems can develop students' creativity in choosing words and arranging words to produce literary works that have aesthetic value.
\end{abstract}

Keywords: Language Style, Comparison, Poetry, Literature Learning

\section{PENDAHULUAN}

Bahasa merupakan medium untuk menyampaikan pikiran, pengalaman, ide, dan perasaan yang pernah dialami oleh manusia. Manusia menggunakan bahasa sebagai alat dan media untuk manyampaikan maksud dan tujuannya, karena dalam bahasa memiliki sistem bunyi, lambang, dan makna yang terkandung serta pesan yang disampaikan. Hal ini terlihat salah satu media yang dapat digunakan oleh manusia dalam menyampaikan gagasan, ide, dan pengalaman serta perasaan dengan menggunakan bahasa yaitu karya sastra. Sastra merupakan suatu karya yang bersifat imajinatif menggunakan segala perasaan atau pikiran melalui ekspresi diri dengan 
bahasa serta nilai keindahan dalam penyampaiannya. Karya sastra yang memperlihatkan dan mempertahankan bahasa sebagai nilai keindahannya adalah puisi (Wulandari, Suyatno, dan Fuad, 2015:1-10)

Puisi merupakan luapan perasaan penyair melalui kata-kata indah yang dirangkai untuk menyampaikan perasaan penulis. Dalam puisi, rangkaian kata tersebut dikemas dalam bentuk singkat, padat, dan mewakili perasaan penyair serta mengandung keindahan. Kurniawan dan Sutardi (2010:25) berpendapat bahwa, puisi adalah ungkapan perasaan atau ekspresi perasaan yang dituliskan dengan bahasa yang indah. Selain itu, manusia dapat menggunakan bahasa untuk mengekspresikan emosi, perasaan, pengalaman, pikiran atau gagasan melalui puisi. Dengan puisi pula, manusia akan sadar dirinya untuk mengamati, mengagumi, atau memikirkan lingkungan alam di sekitarnya.

Kosasih (2012:97) mengatakan puisi adalah bentuk karya sastra yang menggunakan kata-kata indah dan kaya makna. Puisi merupakan karya sastra menggunakan bahasa yang berbeda dengan yang digunakan sehari-hari. Kata-kata dalam puisi memiliki banyak makna merupakan kata konotatif pengertiannya memiliki banyak penafsiran. Selain itu, Djojosuroto (2005:15) menambahkan bahwa puisi yang baik ialah puisi dibangun dengan mengonsentrasikan unsur intrinsik dan ekstrinsik atau yang biasa disebut struktur fisik dan batin. Struktur fisik adalah struktur dilihat melalui bahasa yang tampak terdiri atas: (1) diksi, (2) pencitraan, (3) gaya bahasa, dan (4) persajakan. Sedangkan struktur batin adalah makna yang terkandung dalam puisi tidak secara langsung dapat dihayati terdiri atas: (1) tema, (2) nada, (3) suasana, dan (4) amanat.
Struktur puisi tersebut memperlihatkan bahwa penggunaan bahasa sebagai nilai keindahan dalam karya sastra semakin jelas. Selain itu, penggunaan bahasa sangat berkaitan dengan gaya bahasa yang dimiliki oleh manusia itu sendiri untuk menciptakan keindahan dalam menulis puisi. Kemudian, manusia menulis puisi harus mengandung nilai estetik karena gaya bahasa yang disampaikan akan memperlihatkan kualitas tulisan tersebut dan dapat mengundang kekaguman seorang pembaca. Hal inilah yang memperlihatkan bahwa bahasa dalam puisi sebagai aspek keindahan dalam menyampaikan pesan kepada pembaca. Oleh karena itu, terlihat gaya bahasa merupakan salah satu unsur terpenting dalam puisi. Dengan adanya penggunaan gaya bahasa dalam karya sastra khususnya puisi akan menimbulkan kesan indah pada puisi (Laila, 2016:146-163).

Gaya bahasa yang digunakan manusia dalam menulis puisi memiliki peranan yang sangat penting, karena gaya bahasa inilah yang akan memperlihatkan keindahan setiap kata-kata yang dituliskan. Tarigan dalam Wulandari dkk, (2015:1-10) berpendapat bahwa gaya bahasa adalah bahasa indah yang digunakan untuk meningkatkan efek dengan jalan memperkenalkan serta membandingkan suatu benda atau hal tertentu dengan benda atau hal lain yang lebih umum. Hal yang menjadi unsur pembangun gaya bahasa selain memberikan kesan keindahan dalam puisi, gaya bahasa sebagai unsur membandingkan benda tertentu dengan benda lainnya sehingga memperkaya makna pada puisi.

Gaya bahasa dapat diartikan sebagai cara khas manusia dalam menuliskan sesuatu hal. Dalam menulis puisi setiap menusia memilik cara yang berbeda dalam mengungkapkan gagasan, ide, pengalaman, dan perasaan. Perbedaan ini akan memperlihatkan kepribadian menusia dalam 
menggunakan bahasa. Karena pembendaharaan kata dan pemilihan kata dalam menulis inilah yang menjadi cara khas seorang manusia dalam menggunakan bahasa. Hal ini senada dengan pendapat Keraf dalam Rahman dan Anto (2015:9-15) mengatakan bahwa gaya bahasa adalah cara mengungkapkan pikiran melalui bahasa secara khas yang memperlihatkan jiwa dan kepribadian penulis (pemakai bahasa).

Banyak jenis gaya bahasa yang digunakan oleh menusia dalam menulis suatu karya sastra terutama puisi. Agni (2009:11-12) menyebutkan jenis-jenis gaya bahasa atau majas yakni perbandingan, sindiran, penegasan, dan pertentangan. Keempat jenis gaya bahasa ini yang sering digunakan oleh manusia dalam menulis. Namun, dalam puisi lebih banyak menggunakan gaya bahasa perbandingan, karena gaya bahasa ini lebih membandingkan benda dengan kata lain dalam bahasa kiasan. Kosasih (2008:35) berpendapat bahwa perbandingan adalah bahasa yang digunakan oleh penyair untuk mengatakan sesuatu dengan cara membandingkan. Mengiaskan atau menyamakan sesuatu dengan yang lainnya agar gambaran benda yang dibandingkan itu lebih jelas. Gaya bahasa pada puisi lebih menggunakan bahasa konotatif untuk membandingkan sesuatu hal dan rangkaian kata tersebut tidak langsung kepada makna yang sebenarnya. McMahan (1992:480) menambahkan bahwa metaphor and simile $A$ is an imaginative comparison that makes use of the connotative values of words. Comparison would usually be called similes, but you can also find similes that use as and other explicitly comparative words. In fact, you may use the broader term metaphor to refer to a figure of speech that is either a metaphor and simile. Hal ini dapat diartikan gaya bahasa perbandingan merupakan gaya bahasa

perumpamaan yang membandingkan sesuatu benda dengan benda lain. Dalam gaya bahasa perbandingan terdapat gaya bahasa metafora dan simile. Metafora dan simile merupakan gaya bahasa perbandingan imajinasi menggunakan nilai konotatif dari kata-katanya. Gaya bahasa ini biasanya disebut perumpamaan, karena gaya bahasa tidak menggunakan kata-kata denotatif melainkan menggunakan kata-kata konotatif untuk mengumpamakan sesuatu benda.

Pada gaya bahasa perbandingan masih banyak macam di antaranya: (1) Alegori, (2) Alusio, (3) hiperbola, (4) metafora, (5) personifikasi, (6) simile, (7) sinekdoke (pars pro toto dan totum pro parte). Dalam proses pembelajaran sastra di SMA khususnya puisi, potensi pembelajaran sastra sebagai alat untuk belajar dan pengembangan bahasa sangat besar. Namun, pada kenyataannya pembelajaran sastra di SMA dan kehidupan sehari-hari kurang bermakna, masih banyak siswa kurang pengetahuan dan memahami gaya bahasa yang ada dalam puisi. Hal ini terjadi karena kurangnya siswa dalam menganalisis puisi dari segi gaya bahasa, sehingga siswa merasa pembelajaran puisi sangat sulit, serta memaknai puisi sesuai imajinasi dan pemahaman secara mendalam untuk mengetahui pesan yang disampaikan. Selain itu, permasalah lain yang terjadi masih banyak guru yang kurang menggunakan kumpulan puisi dalam pembalajaran puisi dan menganalisis beberapa puisi yang ada dalam kumpulan puisi dari segi gaya bahasa. Faktor ini terjadi banyak kemungkinan salah satuhnya guru tidak mengindahkan, atau tidak perlu media lain yang mendukung dalam pembelajaran puisi, dan menganggap cukup dengan buku paket/LKS yang tersedia di sekolah. Padahal dengan menggunakan buku kumpulan puisi dapat dijadikan sebagai alternatif media tambahan dalam memahami 
puisi-puisi yang ada dari segi gaya bahasa terutama gaya bahasa perbandingan.

Berkaitan pembelajaran sastra di SMA yang diajarkan kepada siswa di sekolah. Dalam pelajaran bahasa Indonesia dengan materi gaya bahasa merupakan aspek yang harus dikuasai oleh siswa dalam pembelajaran puisi. Pengajaran sastra mengenai gaya bahasa merupakan aspek terpenting untuk meningkatkan pengetahuan dan pemahaman siswa dalam mempelajari puisi. Siswa harus dapat mengikuti pembelajaran sastra ini dan menganalisis puisi dari materi gaya bahasa sesuai yang tercantum dalam kurikulum 2013.

Pembelajaran sastra di SMA harus sesuai dengan kurikulum 2013. Dalam kurikulum 2013 dalam mata pelajaran bahasa Indonesia yaitu kompetensi dasar (KD) 3.17 yaitu menganalisis unsur pembangun puisi, sedangkan indikator pencapaian kompetensi 3.17.2 yaitu menganalisis gaya bahasa dalam puisi. Dengan adanya kompetensi dasar ini siswa selalu dilatih untuk menganalisis gaya bahasa yang terdapat dalam puisi, sehingga akan timbulnya kesadaran siswa dalam pemahamani dan menghargai serta aktif dalam pembelajaran sastra.

Hardiningtyas dalam Umami, (2018:70) mengemukakan bahwa pembelajaran sastra bertujuan untuk menanamkan nilai-nilai moral, etika, budi pekerti, dan kemanusiaan pada siswa. Pembelajaran sastra dapat melatih siswa untuk menanamkan nilai-nilai kehidupan yang sesuai dengan norma yang berlaku. Selain itu, siswa dapat menghargai suatu karya sastra dengan baik dan memaknai karya sastra dengan melihat gaya bahasa yang digunakan oleh penulis. Demikian siswa dengan mudah menciptakan sebuah karya sastra yang mengandung nilai-nilai keindahan dalam penggunaan bahasa itu sendiri.
Kumpulan puisi dapat dijadikan sebagai media alternatif pembelajaran sastra salah satunya yaitu kumpulan puisi Kwatrin Untuk Kekasih karya Waluya Ds. Kumpulan puisi ini terdapat variatif penggunaan gaya bahasa dan bahasa yang digunakan oleh penulis sangat ringan untuk dipahami. Kemudian puisi-puisi yang ada dalam kumpulan puisi ini memberikan makna dan rasa yang berbeda disetiap larik dan baitnya. Kemudian gaya bahasa yang digunakan oleh penulis sesuai dengan keadaan siswa pada zaman sekarangnya ini. Oleh karena itu, kumpulan puisi Kawatrin Untuk Kekasih karya Waluya Ds dapat dianalisis/teliti dari aspek gaya bahasa terutama gaya bahas perbandingan.

\section{METODE}

Metode yang digunakan dalam penelitian ini adalah metode deskriptif kualitatif dengan teknik analisis isi. Penulis berusaha mendeskripsikan gaya bahasa perbandingan pada kumpulan puisi Kwatrin Untuk Kekasih Karya Waluya Ds dalam Pembelajaran Sastra di SMA. penelitian kualitatif adalah penelitian untuk memahami fenomena tentang apa yang dialam oleh objek penelitian. Secara holistik, dengan cara deskripsikan dalam bentuk kata-kata dan bahasa, dan pada suatu konteks khusus yang alamiah dan dengan memanfaatkan berbagai metode ilmiah (Moleong, 2007:6).

\section{HASIL DAN PEMBAHASAN}

Dalam penelitian ini, peneliti memfokuskan gaya bahasa perbandingan pada kumpulan puisi Kwatrin Untuk Kekasih karya Waluya Ds. Pada kumpulan puisi ini penulis sangat variatif dalam menggunakan gaya bahasa. Hal ini terlihat bahasa yang digunakan sangat ringan serta memiliki arti yang mendalam, sehingga memberikan makna dan rasa yang berbeda disetiap isi puisi tersebut. Gaya bahasa perbandingan dalam penelitian ini yaitu alegori, alusio, hiperbola, metafora, personifikasi, simile, dan sinekdoke (pars pro toto dan totum pro 
parte). Berikut ini penggalan puisi yang ada dalam kumpulan puisi Kwatrin Untuk Kekasih karya Waluya Ds.

\section{Alegori}

Alegori adalah gaya bahasa yang menyatakan dengan cara lain, melalui kiasan atau penggambaran yang digunakan. Terdapat gaya bahasa alegori pada judul puisi Bulan Jatuh Di Lautan. Penggalan puisi dapat dilihat di bawah ini.

Bulan jatuh di lautan

Retak ditelan ombak

Seperti keping-keping mimpiku

Di derak riak menuju pantaimu.

Penggalan puisi di atas menunjukkan gaya bahasa alegori. Hal ini terlihat pada bait tersebut yaitu Bulan jatuh di lautan, Retak ditelan ombak, Seperti keping-keping mimpiku, Di derak riak menuju pantaimu. Pada larik Bulan jatuh di lautan, Retak ditelan ombak ini terlihat penggambaran bahwa sebuah harapan yang tidak sesuai kenyataan sehingga membuatnya jatuh dan hancur terlalu dalam. Kemudian, pada larik Seperti keping-keping mimpiku, Di derak riak menuju pantaimu menunjukkan bahwa ia tetap berusaha menuju sesuatu yang diharapkan walaupun ia tahu mimpi dimiliki telah hancur. Namun, ia tetap berusaha sampai kepengujung pengharapan yang diyakininya.

Terdapat gaya bahasa yang menunjukkan alegori pada judul puisi Waktu Gerimis Hampir Berhenti. Hal ini didukung oleh penggalan puisi di bawah ini.

Gemerlap laut.

Gelombang menyusup kanal

Di antara pasang dan surut

Mengurai kisah cinta yang kuhafal

Penggalan di atas menunjukkan gaya bahasa alegori pada bait Gemerlap laut, Gelombang menyusup kanal, Di antara pasang dan surut, Mengurai kisah cinta yang kuhafal. Pada larik Gemerlap laut, Gelombang menyusup kanal menggambarkan keindahan lautan yang dijadikan sebagai keindahan dalam menjalani sebuah hubungan. Kemudian menemukan permasalah yang berusaha masuk merusak keindahan hubungan tersebut. Kemudian pada larik Di antara pasang dan surut, Mengurai kisah cinta yang kuhafal terlihat bahwa seseorang yang menemukan kebahagian dan permasalahan atau kejenuhan dalam menjalani hubungan, sehingga menguraikan percintaan yang sudah dijalani dan menemukan solusi untuk mengatasi ketika terjadi pasang dan surut dalam menjalin hubungan.

Pada puisi berjudul Sonata Untuk Sekuntum Bunga terdapat gaya bahasa yang menunjukkan alegori ada dalam penggalan puisi di bawah ini.

\section{Adakah kumbang yang mampu menolakmu \\ bergoyang cemerlang di bawah terang matahari}

Penggalan puisi di atas menujukkan gaya bahasa alegori pada larik Adakah kumbang yang mampu menolakmu, bergoyang cemerlang di bawah terang matahari. Larik ini memberikan gambaran bahwa tidak ada seorang laki-laki yang bisa menolak seorang perempuan yang ia sukai. Selain itu, laki-laki yang tidak bisa lepas padangannya karena kekagumanan dan terpesona terhadap kecantikan seorang perempuan yang kecantikan terpancar di bawah sinar matahari.

Terdapat gaya bahasa alegori pada judul puisi Cinta Tak Mengenal Bahasa. Hal ini didukung oleh penggalan puisi di bawah ini.

Kalau saja kau biarkan aku
memelukmu
$\begin{aligned} & \text { Akan kau rasa gejolak kelepak } \\ & \text { sukmaku }\end{aligned}$


Penggalan puisi di atas menujukkan gaya bahasa alegori pada larik Kalau saja kau biarkan aku memelukmu, Akan kau rasa gejolak kelepak sukmaku, karena terlihat jika seseorang diizinkan untuk dapat memeluk seorang yang disukai, perasaan ia sangat senang dan bahagia. Hal ini ditunjukkan juga detak jantung yang begitu bergejolak dengan penuh rasa bahagia dan cinta saat kau memeluk dirinya.

\section{Alusio}

Alusio adalah gaya bahasa yang mensugestikan kesamaan antara orang, tempat dan peristiwa. Terdapat gaya bahasa alusio pada judul puisi Bulan Jatuh Di Lautan. Dalam hal ini terlihat pada penggalan puisi di bawah ini.

--Seperti Sisyhus selalu terus

mendorong batu dengan sia-sia

Tanpa pernah putus asa--.

Penggalan puisi di atas menunjukkan gaya bahasa alusio pada bait Sisyhus selalu terus mendorong batu dengan sia-sia tanpa putus asa, berarti penyair berusaha mensugestikan orang yang tetap berusaha menerjang batu karang sekuat tenaga tanpa putus asa. Selain itu, tetap bertahan kepada harapan yang sudah hancur berkepingkeping serta masih yakin harapan itu masih ada dan tidak akan sia-sia.

Terdapat gaya bahasa alusio pada judul puisi Kisah Cinta Kita. Hal ini didukung oleh penggalan puisi di bawah ini.

\section{Kisah cinta abadi tidak harus dari tragedi \\ Roro Mendur Pronocitro, Layla Majnun, juga \\ Sampek Engtay serta Joyo Prono Layonsari \\ Kisah mereka terdengar dari masa ke masa.}

Penggalan puisi di atas terdapat gaya bahasa alusio pada bait Kisah cinta abadi tidak harus dari tragedy, Roro Mendur Pronocitro, Layla Majnun, juga, Sampek Engtay serta Joyo Prono Layonsari, Kisah mereka terdengar dari masa ke masa. Hal ini terlihat penyair berusaha mensugestikan kisah cinta abadi untuk dua orang saling mencintai tidak harus sama seperti cerita para tokoh roman. Kisah cinta abadi tidak harus terdengar oleh semua orang, cukup dua insan yang menjalani dengan penuh romantis dan kebahagiaan itu akan menjadi abadi sepanjang hidup.

Pada puisi berjudul Dengan Puisi Kali Ini terdapat gaya bahasa alusio. Berikut dapat dibuktikan dengan penggalan puisi di bawah ini.

Parahiyangan yang jelita kujamah seluruh tanah lembah dan pegunungan seolah tanpa dosa terlentang membujur

dari Ciawi, Puncak, sampai Cianjur.

Penggalan puisi di atas terdapat gaya bahasa alusio pada larik Parahiyangan yang jelita kujamah menggambarkan bahwa penyair mensugestikan tempat yang indah di jawa barat dari pegunungannya. Keindahan ini terlihat dari lembah dan pegunungan yang begitu indah dipandang oleh mata, seakan keindahan itu terlihat tanpa adanya dosa yang ada di sepanjang Ciawi sampai Cianjur. Selain itu, daerah bergunung ini dipercayai tempat tinggal para dewa yang oleh masyarakat setempat.

\section{Hiperbola}

Hiperbola adalah gaya bahasa yang pengungkapannya berlebih-lebihan sehingga tidak masuk akal. Terdapat gaya bahasa hiperbola pada judul puisi Waktu Gerimis Hampir Berhenti. Hal ini didukung oleh penggalan larik di bawah ini.

Haripun semakin cerah

Di sini aku terbakar gairah. 
Penggalan puisi di atas termasuk golongan gaya bahasa hiperbola, terlihat pada larik Di sini aku terbakar gairah yang menunjukkan bahwa seseorang yang dirinya terbakar oleh keinginan yang kuat. Padahal gairah terbakar ini menyatakan untuk kecerahan sinar matahari seakan hasratnya terbakar atau semangat yang begitu tinggi yang ditunjukkan seseorang kepada orang lain.

Terdapat gaya bahasa hiperbola pada judul puisi Kisah Cinta Kita. Hal ini didukung oleh penggalan larik di bawah ini.

Kau dan aku bagai sepasang kupukupu

Di antara kembang-kembang di taman Terbang melayang mesra bercumbu

Penggalan puisi di atas terdapat gaya bahasa hiperbola pada larik Terbang melayang mesra bercumbu. Pada larik ini terlihat berlebihan karena seorang sedang membayangan kekasihnya dengan begitu gembira, sedangkan yang terjadi membanyangkan sesuatu kenangan terindah yang pernah dilalui berdua sepasang kekasih.

Terdapat gaya bahasa hiperbola pada judul puisi Sonata Untuk Sekuntum Bunga. Berikut penggalan puisi yang mendukung di bawah ini.

sejak pertama kita berjumpa tak bisa kulupa

garis-garis anggun wajahmu yang ayu seperti lekak-lekuk pelik pena di sketsa.

Penggalan puisi di atas terdapat gaya bahasa hiperbola pada larik sejak pertama kita berjumpa tak bisa kulupa dan garis-garis anggun wajahmu yang ayu, yaitu seorang yang tidak bisa melupakan wajah wanita untuk pertama kali berjumpa denganya. la selalu teringat kecantikan atau keindahan yang dimiliki wanita tersebut. Pada kenyataannya ketika seorang senang terhadap orang lain tidak harus melihat kecantikan orang tersebut apalagi untuk pertama kali bertemu.

Terdapat gaya bahasa hiperbola pada puisi Sendiri Di Gondola. Berikut penggalan puisi di bawah ini.

\section{Dari pelabuhan ke pelabuhan mencarimu \\ Untuk menguraikan rinduku}

Pada penggalan puisi di atas terdapat gaya bahasa hiperbola pada larik Dari pelabuhan ke pelabuhan mencarimu dan Untuk menguraikan rinduku. Hal ini terlihat seorang yang mencari kekasihnya di pelabuhan untuk menceritakan segala rindunya. Namun, pada realitanya untuk menceritakan kerinduan tidak selalu di pelabuhan dapat dilakukan di mana saja. Walaupun pelabuhan memiliki kenangan tersendiri untuk seseorang.

Terdapat gaya bahasa hiperbola pada puisi berjudul Cinta Tak Mengenal Bahasa. Hal ini didukung oleh penggalan larik di bawah ini.

\section{Cintaku tak mengenal bahasa}

karena kata-kata bisa kehilangan makna.

Gaya bahasa hiperbola pada larik cintaku tak mengenal bahasa berarti cinta tidak perlu diungkapkan melalui bahasa atau kata-kata. Namun, pada kenyataanya cinta itu membutuhkan bahasa untuk menyakinkan dan mengungkapkan perasaan agar orang tersebut percaya apa yang dikatakannya.

\section{Metafora}

Metafora adalah gaya bahasa yang pengungkapanya berupa perbandingan analogis yang menghilangkan kata seperti layaknya, bagaikan, dan lain-lain. Terdapat gaya bahasa metafora pada judul puisi Bulan Jatuh Di Lautan. Berikut penggalan puisi di bawah ini. 
Harapan hanyalah jalan membasuh luka

Agar tidak terus menganga

Gaya bahasa metafora yang terdapat dalam penggalan puisi di atas pada larik Harapan hanyalah jalan membasuh luka, berarti membandingkan sebuah harapan dengan jalan membasuh luka dengan keinginan yang akan dicapai, sebanarnya harapan tidak semua tercapai dengan mudah. Dalam harapan yang diinginkan harus ada usaha untuk mencapainya serta harapan dapat dijadikan jalan satusatunya untuk membersihkan luka/kekecewaan hati yang tersakiti.

Terdapat gaya bahasa metafora pada judul puisi Bisakah Kau Sebut Namaku. Dalam penggalan puisi di bawah ini.

Menunggu adalah saat yang terindah buat menanti harapan untuk merekah.

Dalam penggalan puisi di atas terdapat penggunaan gaya bahasa metafora pada larik Menunggu adalah saat yang terindah, berarti membandingkan menunggu itu sesuatu yang indah untuk menanti harapan yang akan berbuah hasil yang baik. Apabila hanya menunggu tanpa ada perbuatan segala sesuatu pastinya tidak akan sesuai dengan harapan. Oleh karena itu, berusaha melakukan sesuatu untuk mewujudkan harapan yang diinginkan.

\section{Personifikasi}

Personifikasi adalah gaya bahasa perbandingan sesuatu yang menggambarkan benda mati atau bernyawa. Terdapat gaya bahasa personifikasi pada judul puisi Dengan Puisi Kali Ini. Hal ini dapat didukung oleh penggalan puisi di bawah ini.

Angin berbisik lewat daun-daun yang berisik

rintih lirih tangismu
Terdapat gaya bahasa personifikasi terletak pada larik Angin berbisik lewat daundaun yang berisik. Larik ini menggambarkan bahwa angin dan daun merupakan benda mati yang bergerak, terlihat angin ibarat manusia yang berbisik kepada temannya disebelahnya. Padahal angin dan daun tidak berbisik karena angin mengenai daun seolah-olah suara daun-daun berbisik ke daun yang lainnya.

Terdapat gaya bahasa personifikasi pada judul puisi Ketika Angin Mengecup Bunga. Hal ini dapat dibuktikan dengan penggalan puisi di bawah ini.

Ketika angin mengecup bunga

dan embum membasuh debu

Gaya bahasa personifikasi yang terdapat dalam puisi terlihat pada larik Ketika angin mengecup bunga". Penggambaran pada larik ini berarti seakan-akan angin mencium bunga selayaknya manusia yang bisa mencium harumnya bunga. Padahal angin merupakan benda mati yang tidak bisa mencium bunga. Kemudian pada larik selanjutnya "embun membasuh debu" dapat dimaknai embun yang sedang membersihkan daun di pagi hari karena terkena kotoran sedangkan manusia yang sedang membasuh muka dengan air. Padahal embun merupakan benda mati yang tidak bisa membersihkan diri.

Terdapat gaya bahasa personifikasi pada judul puisi Bisakah Kau Sebut Namaku. Dapat dibuktikan dengan penggalan puisi di bawah ini.

Pada bulan telah kubisikkan mantra agar tetap mengirim cahaya lewat jendela

Penggambaran gaya bahasa personifikasi terdapat dalam puisi ini pada larik Pada bulan telah kubisikkan mantra. Pada penggalan larik ini terlihat penyair membandingkan bulan seakan manusia 
yang sedang membaca mantra dan manusia berkerja sebagai paranormal. Bulan di sini memberikan cahaya yang indah ketika malam dan membuat manusia kegum yang melihatnya.

\section{Simile}

Simile adalah gaya bahasa perbandingan yang membandingkan kata atau kelompok kata dengan arti bukan sesungguhnya untuk membandingkan suatu benda dengan benda lainnya menggunakan kata seperti, layaknya, bagai, bagaikan, laksana, dan lain-lain. Terdapat pada judul puisi Kisah Cinta Kita. Hal ini didukung oleh penggalan puisi di bawah ini.

\section{kau dan aku bagai sepasang kupu- kupu \\ di antara kembang-kembang di taman}

Dalam penggalan puisi di atas terdapat gaya bahasa simile pada larik Kau dan aku bagai sepasang kupu-kupu. Hal ini terlihat adanya membandingkan antara kenangan indah yang pernah dijalani kau dan aku seperti sepasang kupu-kupu yang indah saat terbang, dan mengepakkan sayapnya selalu memberinya warna yang tidak bisa terpisahkan. Perbandingan ini dengan melambang kupu-kupu yang sebagai sepasang kekasih yang menjalani hubungan yang mesra.

tanpa harus saling memiliki seperti Yin Yang bersenyawa sepanjang masa.

Pada larik selanjutnya masih dalam puisi yang sama yaitu Seperti Ying Yang bersenyawa. Penggalan larik ini membandingkan bahwa Ying Yang bersenyawa yakni segala sesuatu yang berlawanan tetapi berusaha saling melengkapi. Selain itu, seseorang yang memiliki rasa yang sama kepada orang lain tetapi tidak bisa saling memiliki sehingga diibaratkan Ying Yang. Karena perbandingan ini artikan seseorang yang selalu berusaha walaupun ia tahu kemungkinan kecil akan berhasil dan dapat saling melengkapi

Terdapat gaya bahasa simile pada judul puisi Sonata Untuk Sekuntum Bunga. Berikut ini terlihat pada penggalan puisi di bawah ini.

Seperti kembang yang mekar di hatiku sejak pertama kita berjumpa tak bisa kulupa

garis-garis anggun wajahmu yang ayu seperti lekak-lekuk pelik pena di sketsa.

Dalam puisi tersebut terdapat gaya bahasa simile pada larik Seperti kembang yang mekar di hatiku. Pada larik ini berarti membandingkan kembang yang bermekaran di hati yaitu mengibaratkan hati yang berbunga-bunga atau bahagia. Pengibaratan ini digunakan seakan hati seorang yang senang sebagai bunga bermekaran enak dipandang. Kemudian pada larik Seperti lekak-lekuk pelik pena di sketsa terlihat penyair membandingkan bahwa garis kecantikan seorang wanita yang sangat indah dilihat. Hal ini terlihat lekak-lekuk yang amat indah seakan lukisan yang memiliki nilai estetis.

Terdapat gaya bahasa simile pada puisi Cinta Tak Mengenal Bahasa. Hal ini didukung oleh penggalan larik di bawah ini.

\section{akan kau rasa gejolak kelepak sukmaku \\ bagai kupu-kupu merindukan madu indah terbang melayang}

Terdapat gaya bahasa simile dalam puisi di atas, terlihat pada larik Bagai kupukupu merindukan madu. Hal ini terlihat penyair membandingkan seekor kupu-kupu yang tidak mengisap madu pada bunga, mengibaratkan seorang yang merindukan pujaan hati yang dicintainya. Selain itu, 
adanya kesamaan madu sebagai kekasih yang selalu dirindukannya.

Terdapat gaya bahasa simile pada puisi Ketika Angin Mengecup Bunga. Dalam hal ini didukung oleh penggalan larik di bawah ini.

Seperti angin yang menyejukkan.

Seperti angin yang menggairahkan api. Seperti angin yang bermain dengan awan.

Darimu tanpa kau tahu kurasakan kepuasan hati.

Penggalan puisi di atas, terlihat gaya bahasa simile pada larik seperti angin yang menyejukkan, Seperti angin yang menggairahkan api, Seperti angin yang bermain dengan awan. Penggambaran yang ada dalam larik ini yaitu penyair berusaha membandingkan angin yang selalu memberikan kesejukan, menggairahkan api, dan bermain dengan awan. Artinya, angin selalu memberikan kesabaran kepada seorang yang tabah menjalani hidup. Selain itu, memberikan rasa semangat yang tiada henti-hentinya dan angin yang selalu bergerak membawa awan ke sana kemari. Dengan pengibaratan ini penyair secara tidak langsung memberikan gambaran manusia yang selalu berusaha dalam keadaan apapun selama itu memberikan kebahagiaan di hati.

Terdapat gaya bahasa simile pada judul puisi Dengan Puisi Kali Ini. Hal ini didukung oleh penggalan puisi di bawah ini.

lekak-lekuk garis tubuhmu

Berkelebat lewat seperti mimpi

Kuperangkap dengan kata dibuku

Terdapat gaya bahasa simile dalam puisi di atas, terlihat pada larik Berkelebat lewat seperti mimpi. Pada penggalan larik ini dapat diartikan bahwa seorang yang melihat tubuh wanita yang dirindukan bergerak begitu cepat dihadapanya. Selain itu, seperti mimpi yaitu memberikan gambaran seorang yang heran melihat keindahan yang belum pernah ia lihat secara langsung.

\section{Sinekdoke}

Sinekdoke adalah gaya bahasa yang mempergunakan sebagian dari sesuatu hal untuk menyatakan keseluruhan (Pars pro toto) atau mempergunakan keseluruhan untuk menyatakan sebagian (Totum pro parte).

\section{Pars pro toto}

Pars pro toto merupakan gaya bahasa yang mempergunakan sebagian dari sesuatu hal untuk menyatakan keseluruhan. Terdapat pada puisi Waktu Gerimis Hampir Berhenti. Di bawah penggalan puisi yang mendukung sebagai gaya bahasa sinekdoke (pars pro toto).

Terdengar jejak tapak kaki verdi

Gaya bahasa yang terdapat dalam penggalan puisi di atas ialah pars pro toto pada larik jejak tapak kaki verdi. Larik ini memberikan penggambaran bahwa terdengar suara jejak tapak kaki Verdi yang sudah menyatakan sebagian tubuhnya untuk seluruh tubuhnya. Padahal ia langsung melihat Verdi ketika berjalan kaki menujunya.

Terdapat pada judul puisi Dengan Puisi Kali Ini. Dalam hal ini didukung oleh penggalan larik di bawah ini.

\section{Lekak-lekuk garis tubuhmu}

Gaya bahasa yang terdapat dalam penggalan puisi di atas ialah pars pro toto pada larik Lekak-lekuk garis tubuhmu. Hal ini memberikan gambaran menyatakan sebagian garis tubuh, namun garis tubuh seluruh bagian tubuhnya. Selain itu, seorang yang langsung melihat lekukan tubuh indah itu

Terdapat pada puisi Sonta Untuk Sekuntum Bunga. Dalam hal ini didukung oleh penggalan larik di bawah ini.

garis-garis anggun wajahmu yang ayu 
Gaya bahasa yang terdapat dalam penggalan puisi di atas ialah pars pro toto pada larik garis-garis anggun wajahmu yang ayu. Artinya penggalan puisi ini yaitu garisgaris anggun wajahnya sebagian tubuhnya, tetapi garis-garis anggun wajahnya untuk keseluruhan tubuhnya. Seorang yang langsung melihat keanggunan wanita yang ia lihat secara langsung.

\section{Totum pra porte}

Totum pra porte adalah gaya bahasa yang mempergunakan keseluruhan untuk menyatakan sebagian. Terdapat pada judul puisi Sendiri Di Gondola. Hal ini didukung oleh penggalan puisi di bawah ini.

Kulihat wajah-wajah cerah bahagia

Saat aku di Gondola seorang diri

Gaya bahasa yang terdapat dalam penggalan puisi di atas ialah totum pro parte pada larik Kulihat wajah-wajah cerah bahagia Saat aku di Gondola seorang diri. Ini memberikan gambaran bahwa seseorang melihat semua orang dengan wajah cerah saat di gondola, sebenarnya hanya sedikit yang berwajah cerah saat di gondola. Dalam hal ini, penggalan tersebut merupakan gaya bahasa sinekdoke (totum pra porte).

\section{Pembelajaran Sastra di SMA}

Pembelajaran sastra di SMA adalah suatu kegiatan yang dilakukan siswa dalam melatih dan mempertajam pengetahuan serta pemahaman terhadap bahasa dan nilai-nilai yang ada dalam karya sastra terutama puisi. Karya sastra yang baik harus mengandung nilai positif untuk siswa dalam menikmati dan menghargai sebuah karya sastra. Selain itu, unsur terpenting dalam puisi yang memiliki keindahan bahasa terletak pada gaya bahasa. Gaya bahasa yang digunakan dalam puisi akan membawa siswa untuk menyenangi dan menyukai serta memaknai karya sastra secara mendalam.
Oleh karena itu, dalam pembelajaran sastra di SMA pada aspek gaya bahasa harus lebih ditekan dan difokuskan agar siswa dapat mempertajam akal untuk mengartikan dan memaknai kata-kata dalam larik dan bait pada puisi. Dengan begitu, siswa dapat mengetahui pesan yang disampaikan penulis dalam menggunakan kata-kata yang indah pada puisi.

Dalam mempertajam akal dan pengetahuan serta pemahaman siswa dalam pembelajaran sastra, guru dapat memberikan kumpulan puisi kepada siswa untuk dapat mengidentifikasi, menganalisis, dan merelevansikan dalam kehidupan sehari. Menganalisis puisi dapat meningkatkan daya pikir siswa dalam memahami penggunaan gaya bahasa. Hal ini terlihat pada kumpulan puisi Kwatrin Untuk Kekasih karya Waluya Ds dapat dijadikan alternatif dalam pembelajaran sastra di SMA. Pada kumpulan puisi ini terdapat variatif penggunaan gaya bahasa terutama gaya bahasa perbandingan yang di antaranya: (1) Alegori, (2) Alusio, (3) hiperbola, (4) metafora, (5) personifikasi, (6) simile, (7) sinekdoke (pars pro toto dan totum pro parte). Dengan demikian, pembelajaran sastra di SMA guru lebih variatif dalam memilih media pembelajaran sebagai alternatif pembelajaran sastra. Guru dapat melatih siswa dalam menganalisis dan membuat karya sastra secara kreatif dalam menggunakan gaya bahasa, sehingga siswa dalam dapat menghasilkan sesuatu karya sastra yang memiliki nilai keindahan dalam bahasa baik merangkai kata atau memilih kata yang tepat menjadikan ciri khasnya.

Penulis berusaha memaparkan aplikasi pembelajaran sastra di SMA sesuai kurikulum 2013. Pembelajaran sastra di SMA kurikulum 2013 mengenai gaya bahasa pada puisi terdapat pada kompetensi dasar (KD) 3.17 yaitu menganalisis unsur pembangun puisi, sedangkan indikator pencapaian 
kompetensi 3.17.2 yaitu menganalisis gaya bahasa dalam puisi. Berikut pemaparan aplikasi pembelajaran sastra di SMA mengenai gaya bahasa pada puisi di bawah ini.

1. Guru memberitahu materi yang akan dipelajari mengenai gaya bahasa pada puisi.

2. Guru menjelaskan tujuan pembelajaran.

3. Guru menggali informasi kepada siswa sebelum menjelaskan materi pengajaran gaya bahasa dan menganalisis puisi.

4. Guru menjelaskan pengertian gaya bahasa yang terdapat pada puisi.

5. Guru menjelaskan macam-macam gaya bahasa yang terdapat pada puisi.

6. Guru memberikan contoh puisi yang sudah dianalisis mengenai gaya bahasa kepada siswa untuk dipahami dan memberikan penjelasan mengenai cara mengenalisis puisi.

7. Guru memberikan salah satu contoh puisi yang ada dalam kumpulan puisi Kwatrin Untuk Kekasih karya Waluya Ds kepada siswa, serta menugasi siswa untuk menganalisis puisi tersebut dan memaknainya secara mendalam.

8. Siswa membuat sebuah puisi sesuai yang dirasakan dan pengalaman dengan menggunakan gaya bahasa

9. Siswa secara bergantiamembacakan puisi hasil karyanya di depan kelas.

10. Guru menyimpulkan dan menutup pembelajaran.

\section{PENUTUP}

Puisi adalah suatu karya sastra yang dibuat oleh sastrawan untuk mengungkapkan gagasan, ide, pengalaman, dan perasaan melalui kata-kata yang dirangkai secara indah. Rangkaian kata yang tersusun dalam puisi membentuk nilai estetis, sehingga pembaca merasa kagum dan menikmati puisi secara utuh. Keindahan puisi didukung oleh penggunaan gaya bahasa sebagai unsur utama dalam pembangun puisi. Gaya bahasa adalah bahasa figuratif yang digunakan oleh penulis dalam membuat suatu karya sastra. Gaya bahasa ini banyak macam khususnya gaya bahasa perbandingan di antaranya: (1) Alegori, (2) Alusio, (3) hiperbola, (4) metafora, (5) personifikasi, (6) simile, (7) sinekdoke (pars pro toto dan totum pro parte).

Dalam menganalisis puisi, gaya bahasa sangat berperan besar dalam menentukan makna yang terdapat dalam puisi. Selanjutnya, gaya bahasa perbandingan pada kumpulan puisi Kwatrin Untuk Kesasih sebanyak 9 judul puisi di antaranya: Bulan Jatuh Di Lautan, Waktu Gerimis Hampir Berhenti, Kisah Cinta Kita, Cintaku Tak Mengenal Bahasa, Sendiri Di Gondola, Dengan Puisi Kali Ini, Ketika Angin Mengecup Bunga, Sonata Untuk Sekuntum Bunga, dan Bisahkah Kau Sebut Namaku. Kemudian, penggunaan gaya bahasa perbandingan pada kumpulan puisi tersebut sebanyak 7 gaya bahasa perbandingan yang terdiri dari atas: alegori sebanyak 11, alusio sebnayak 4, hiperbola 9, metafora sebanyak 2 , personifikasi sebanyak 8 , simile sebnayak 15 , dan sinekdoke sebanyak 4 (pars pro toto sebanyak 3 dan totum pro parte sebanyak 1). Oleh karena itu, kumpulan puisi Kwatrin Untuk Kekasih dapat dijadikan sebagai bahan pembelajaran sastra di SMA untuk melatih dan menambah pengalaman siswa dalam memaknai puisi dengan mengetahui penggunaan gaya bahasa. Selain itu, untuk mengembangan kreativitas siswa dalam memilih kata dan merangkai kata-kata sampai menghasilkan karya sastra yang memiliki nilai estetis.

\section{UCAPAN TERIMA KASIH}

Penulis sangat mengucapkan terima kasih kepada Universitas Indraprasta PGRI dan 
pihak-pihak yang membantu penulis dalam menyelesaikan penulisan ini. Ucapan terima kasih disampaikan kepada tim editorial Jurnal El-Banar: Jurnal Pendidikan dan Pengajaran STAI Bani Saleh Bekasi. Penulis menyadari masih banyak kekurangan dalam

\section{REFERENSI}

Agni, B. (2009). Sastra Indonesia Lengkap: Pantun Puisi Majas Peribahasa Kata Mutiara. Jakarta: Hi-Fest Publishing.

Djojosuroto, K. (2005). Puisi Pendekatan dan Pembelajaran. Bandung: Nuansa.

Kosasih, E. (2008). Apresiasi Sastra Indonesia. Jakarta: Nobel Edumedia.

Kosasih, E. (2012). Dasar-dasar Keterampilan Bersastra. Bandung: Yrama Widya.

Kurniawan, H., \& Sutardi. (2010). Penulisan Sastra Kreatif. Yogyakarta: Graha IImu.

Laila, A. (2016). Gaya Bahasa Perbandingan dalam Kumpulan Puisi Melihat Api Bekerja Karya M AAN Mansyur (Tinjauan Stilistika). Jurnal Penelitian Bahasa Dan Sastra Indonesia, 2(2). https://media.neliti.com/media/publicatio ns/79994-ID-gaya-bahasaperbandingan-dalam-kumpulan.pdf

Mc. Mahan, E. (1992). Literature and the Writing Process. New York: Micmillan.

Moleong, L. J. (2007). Metodologi Penelitian Kualitatif Edisi Revisi. Bandung: PT. Remaja Rosdakarya.

Rahman, F., \& Anto, P. (2015). Analisis Lirik Lagu dan Aplikasinya dalam menulis ini. Oleh karena itu, penulis masih membutuhkan saran dan komentar yang membangun penulisan selanjutnya lebih baik lagi.

Pembelajaran Gaya Bahasa serta Puisi di Sekolah Dasar. Jurnal Inovasi Pendidikan Dasar, 1(1). https://jipd.uhamka.ac.id/index.php/jipd/ article/view/8

Umami, S. (2018). Pembelajaran Apresiasi Sastra dan Nilai-Nilai Kemanusiaan (Kajian Novel Bidadari Bermata Bening Karya Habiburrahman El Shirazy. ElBanar: Jurnal Pendidikan Dan Pengajaran, 1(1). https://staibanisaleh.ac.id/ojs/index.php/ EIBanar/article/view/15/6

Wulandari, R. A., Suyanto, E., \& Fuad, M. (2015). Majas dalam Kumpulan Puisi dan Pembelajaran di SMA. Jurnal Kata (Bahasa, Sastra, Dan Pembelajarannya), 3(3). http://jurnal.fkip.unila.ac.id/index.php/BI NDO1/article/view/10401 